\title{
Genistein modulates the effects of parathyroid hormone in human osteoblastic SaOS-2 cells
}

\author{
Wen-Fang Chen ${ }^{1,2}$ and Man-Sau Wong ${ }^{1,3 *}$ \\ ${ }^{1}$ Central Laboratory of the Institute of Molecular Technology for Drug Discovery and Synthesis, Department of Applied Biology \\ and Chemical Technology, The Hong Kong Polytechnic University, Hung Hom, Kowloon, Hong Kong SAR, China \\ ${ }^{2}$ Department of Physiology, Medical College of Qingdao University, Qingdao 266021, China \\ ${ }^{3}$ State Key Laboratory of Chinese Medicine and Molecular Pharmacology, Shenzhen, China
}

(Received 11 August 2005 - Revised 19 December 2005 - Accepted 21 December 2005)

\begin{abstract}
Genistein and parathyroid hormone (PTH) are anabolic agents that stimulate bone formation through their direct actions in osteoblastic cells. In the present study, we aimed to determine whether genistein modulates the actions of PTH in human osteoblastic SaOS-2 cells in an oestrogen-depleted condition. The present results showed that genistein $\left(10^{-8}\right.$ to $\left.10^{-6} \mathrm{M}\right)$ induced alkaline phosphatase (ALP) activity and osteoprotegrin (OPG) expression in SaOS-2 cells in a dose-dependent manner. These effects could be completely abolished by co-treatment with oestrogen antagonist ICI 182780 (7 $\alpha$-[9-[(4,4,5,5,5-pentafluoropentyl)sulfonyl]nonyl]-estra-1,3,5(10)-triene-3,17 -diol). Genistein (at $1 \mu \mathrm{M})$ could stimulate the mRNA expression of receptor activator of NF-кB ligand (RANKL). As OPG and RANKL are known to modulate osteoclastogenesis, the ability of genistein to modulate OPG and RANKL expression in SaOS-2 cells suggested that it might modulate osteoclastogenesis through its direct actions on osteoblastic cells. PTH (at $10 \mathrm{nM}$ ) stimulated ALP activity, induced RANKL mRNA expression and suppressed OPG mRNA expression in SaOS-2 cells, confirming its bi-directional effects on osteoblastic cells. Pre-treatment of SaOS-2 cells with genistein and oestrogen not only enhanced PTHinduced ALP activity, but also attenuated PTH up regulation of RANKL mRNA expression and PTH down regulation of OPG mRNA expression. Taken together, the present study provides the first evidence that genistein could modulate the actions of PTH in human osteoblastic SaOS-2 cells in an oestrogen-depleted condition.
\end{abstract}

Genistein: Parathyroid hormone: Alkaline phosphatase: Osteoprotegrin: Receptor activator of nuclear factor-кB ligand

In Asia, the incidence of osteoporosis-related fractures is low as compared with Western countries (Ross et al. 1991; Anonymous, 1994; Lauderdale et al. 1997). High phyto-oestrogen intake has been considered to be one of the contributing factors for the reduced risk of fracture among Asian women (Goldwyn et al. 2000; Valachovicova et al. 2004). Clinical trials have confirmed that dietary supplementation with isoflavone-enriched soya protein may improve the bone mass of both peri- and postmenopausal women (Potter et al. 1998; Alekel et al. 2000). Animal studies have shown the positive effects of treatment with isoflavones such as genistein and daidzein on bone loss induced by oestrogen deficiency (Anderson et al. 1998; Mei et al. 2001; Greendale et al. 2002; Morabito et al. 2002). The cellular mechanisms by which genistein may prevent bone loss are not fully understood.

Genistein is considered to act via a classical oestrogen receptor (ER)-mediated pathway. Genistein may stimulate ER $\beta$ expression (Anderson et al. 2000; Cusack et al. 2001) and down regulate IL-6 secretion in osteoblastic cells (Chen \& Anderson, 2002). Studies have shown that genistein mimics oestrogen in stimulating the expression of osteoprote- grin (OPG), a member of the TNF receptor superfamily, in cultured bone cells (Yamagishi et al. 2001; Chen et al. 2003). The balance of OPG and the ligand for receptor activator of NF- $\kappa$ B (RANKL), another peptide expressed on the surface of stromal osteoblasts, is critical in the bone resorption process. RANKL stimulates osteoclast differentiation through its receptor (receptor activator of NF-кB; RANK) located on osteoclasts, whereas OPG acts as a decoy soluble receptor for RANKL and prevents its interaction with RANK (Bucay et al. 1998; Lacey et al. 1998; Kong et al. 1999). Thus OPG neutralises RANKL functions and prevents osteoclast differentiation, activity and survival. The RANKL-OPG system plays a crucial role in osteoclastogenesis and the balance of bone remodelling. It appears that the positive effects of genistein on bone might be, at least in part, mediated by the modulation of this cytokine system.

Parathyroid hormone (PTH) plays an important role in $\mathrm{Ca}$ homeostasis and in regulating the rate of bone turnover. Several studies support a possible relationship between PTH and accelerated bone loss following the menopause (Khosla et al. 1997; Masiukiewicz et al. 2000). In postmenopausal women,

Abbreviations: ALP, alkaline phosphatase; E2 , 17 $\beta$-oestradiol; ER, oestrogen receptor; GAPDH, glyceraldehyde-3-phosphate dehydrogenase; MTT, 3-[4, 5-dimethyl thiazol 2-yl]-2, 5-diphenyltetrazolium bromide; OPG, osteoprotegrin; PTH, parathyroid hormone; RANK, receptor activator of NF- $\mathrm{BB}$; RANKL, receptor activator of NF- $\kappa \mathrm{B}$ ligand.

* Corresponding author: Dr Man-Sau Wong, fax +852 23649932, email bcmswong@ polyu.edu.hk 
serum PTH concentration and markers of bone resorption increase with advancing age (Khosla et al. 1997). Women receiving oestrogen therapy can prevent increases in PTH levels and reverse virtually all age-related increases in bone resorption (Khosla et al. 1997; Masiukiewicz et al. 2000). In vivo and in vitro studies have shown that PTH causes biphasic effects on bone. Intermittent administration of PTH increases bone mass, whereas continuous infusion of PTH reduces it (Dempster et al. 1993). The anabolic action of PTH is the result of its positive effect on osteoblast differentiation. The bone resorptive effect of PTH is currently believed to be mediated by cytokines such as RANKL, OPG, colony-stimulatory factor 1 and IL-6 (Greenfield et al. 1996; Onyia et al. 1997; Huang et al. 1998; Yao et al. 1998; Yasuda et al. 1998).

In vivo and in vitro studies have shown that oestrogen can modulate the action of PTH on osteoblast function in an oestrogen-deficient state. Oestrogen can attenuate the PTHinduced IL-6 production (Masiukiewicz et al. 2000) and PTH can stimulate osteoblast function in the presence of oestrogen pre-treatment (Nasu et al. 2000). Although oestrogen replacement therapy has been used to prevent or treat postmenopausal osteoporosis, the potential side effects, i.e. increased risk of endometrial, breast and ovarian cancers, have limited the long-term use of oestrogen replacement therapy (Deady, 2004). Thus, alternative approaches are needed for the prevention and treatment of osteoporosis. The study of the possible skeletal benefits of soyabean isoflavones will provide support for its use in prevention of osteoporosis.

The present study aims to characterise the effects of isoflavone genistein and/or PTH on human osteoblastic SaOS-2 cells in an oestrogen-depleted condition and to determine if genistein modulates the action of PTH on osteoblasts.

\section{Materials and methods}

\section{Culture of human osteoblastic cell line (SaOS-2)}

SaOS-2 cells (ATCC no. HTB-85) were cultured in Dulbecco's Modified Eagle medium supplemented with $10 \%$ fetal bovine serum, penicillin ( $100 \mathrm{units} / \mathrm{ml})$ and streptomycin $(100 \mu \mathrm{g} / \mathrm{ml})$ (Invitrogen, Carlsbad, CA, USA) at a density of $1 \times 10^{4}$ cells $/ \mathrm{cm}^{2}$, with medium changes every $3 \mathrm{~d}$. On the 6th day, cells were transferred to phenol red-free Dulbecco's Modified Eagle medium supplemented with $1 \%$ charcoalstripped fetal bovine serum, penicillin (100 units $/ \mathrm{ml}$ ) and streptomycin $(100 \mu \mathrm{g} / \mathrm{ml})$ for $24 \mathrm{~h}$. Then cells were treated with or without $17 \beta$-oestradiol $\left(\mathrm{E}_{2}\right.$; Sigma, St Louis, MO, USA) $\left(10^{-8} \mathrm{M}\right)$ or genistein $\left(10^{-8}\right.$ to $\left.10^{-6} \mathrm{M}\right)$ (Sigma) for 24 or $48 \mathrm{~h}$. A high but physiological concentration $\left(10^{-8} \mathrm{M}\right)$ of $E_{2}$ was used as a positive control, while the dietary achievable concentration range $\left(10^{-8}\right.$ to $\left.10^{-6} \mathrm{M}\right)$ of genistein was chosen for investigation in the study. For anti-oestrogen treatment, SaOS-2 cells were exposed to $E_{2}$ or genistein in the presence or absence of oestrogen antagonist ICI 182780 (7 $\alpha$-[9-[(4,4,5,5,5-pentafluoropentyl)sulfonyl]nonyl]-estra1,3,5(10)-triene-3,17ß-diol); $10^{-6} \mathrm{M}$; Tocris, Bristol, UK) for 24 or $48 \mathrm{~h}$. For combined treatment, cells were pre-treated with or without $\mathrm{E}_{2}\left(10^{-8} \mathrm{M}\right)$ or genistein $\left(10^{-8}\right.$ to $\left.10^{-6} \mathrm{M}\right)$ for $24 \mathrm{~h}$, followed by treatment with $(1-84)$ human PTH $\left(10^{-8} \mathrm{M}\right.$; Sigma) for another 24 or $48 \mathrm{~h}$.

\section{Cell proliferative assays}

For the growth study, SaOS-2 cells were seeded in ninety-sixwell plates $\left(3 \times 10^{3}\right.$ cells/well) in phenol red-free Dulbecco's Modified Eagle medium supplemented with $1 \%$ charcoalstripped fetal bovine serum for $1 \mathrm{~d}$ and then treated with $\mathrm{E}_{2}$ $\left(10^{-8} \mathrm{M}\right)$, genistein $\left(10^{-8}\right.$ to $\left.10^{-6} \mathrm{M}\right)$ or PTH $\left(10^{-8} \mathrm{M}\right)$ for $48 \mathrm{~h}$. For the combined treatment, cells were pre-treated with or without $\mathrm{E}_{2}\left(10^{-8} \mathrm{M}\right)$ or genistein $\left(10^{-8}\right.$ to $\left.10^{-6} \mathrm{M}\right)$ for $24 \mathrm{~h}$, followed by treatment with $(1-84)$ human PTH $\left(10^{-8}\right.$ M) for another $24 \mathrm{~h}$. As an indirect measure of growth, the 3-[4, 5-dimethylthiazol 2-yl]-2, 5-diphenyltetrazolium bromide (MTT) assay was used as described previously (Denizot \& Lang, 1986). Briefly the medium was removed and replaced with $100 \mu \mathrm{l} \mathrm{MTT}(5 \mathrm{mg} / \mathrm{ml}$; Sigma) in PBS. The plates were incubated for $4 \mathrm{~h}$ at $37^{\circ} \mathrm{C}$, followed by the addition of $100 \mu \mathrm{l}$ lysis buffer $(0.04 \mathrm{M}-\mathrm{HCl}$ in propan-2-ol). The multiwell plates were shaken for $1 \mathrm{~h}$ at room temperature. The signals were detected by using a microplate reader at a wavelength of $595 \mathrm{~nm}$.

\section{Alkaline phosphatase activity}

Quantitative alkaline phosphatase (ALP) activity of the culture was determined by an assay based on the hydrolysis of $p$-nitrophenylphosphate to $p$-nitrophenol by using an ALP detecting kit (Sigma). Treated cells were rinsed three times with PBS and harvested with $100 \mu$ l Nonidet P-40 lysis buffer (20 mMtri(hydroxymethyl)-aminomethane- $\mathrm{HCl}, \quad \mathrm{pH} \quad 7 \cdot 5,150 \mathrm{mM}-$ $\mathrm{NaCl}, 1 \mathrm{~mm}-\mathrm{CaCl}_{2}, 1 \mathrm{~mm}-\mathrm{MgCl}_{2}, 10 \%$ glycerol, $1 \%$ Nonidet $\mathrm{P}-40)$. The buffer was supplemented with protease inhibitors ( $2 \mu \mathrm{g} / \mathrm{ml}$ aprotinin, $2 \mu \mathrm{g} / \mathrm{ml}$ leupeptin, $1 \mathrm{~mm}$-phenylmethylsulfonyl fluoride). Lysates were put on ice for $20 \mathrm{~min}$ and subjected to centrifugation at $14000 \mathrm{rpm}$ for $30 \mathrm{~min}$ at $4^{\circ} \mathrm{C}$. Supernatant fractions were used for ALP activity detection. The ALP activity was determined according to the manufacturer's instructions (Massion \& Frankenfeld, 1972). Briefly, $1.0 \mathrm{ml}$ ALP reagent was mixed with a $20 \mu \mathrm{l}$ sample and incubated for $30 \mathrm{~s}$. Absorbance (A) of the tested sample at $405 \mathrm{~nm}$ using water as reference was first recorded as INITIAL A. The absorbance recorded exactly after 2 min was FINAL A. ALP activity was determined as follows:

$$
\begin{aligned}
\operatorname{ALP}(\mathrm{U} / \mathrm{l})= & ((\mathrm{FINAL}-\mathrm{INITIAL}) / 2 \times \mathrm{TV} \times 1000)) /(18.45 \\
& \times \mathrm{SV} \times \mathrm{LP}),
\end{aligned}
$$

where TV was the total volume $(1.02 \mathrm{ml}), \mathrm{SV}$ was the sample volume $(0.02 \mathrm{ml})$ and LP was the lightpath $(1 \mathrm{~cm})$.

To normalise matrix protein expression to total cellular protein, a fraction of the reaction solution was used in a Bradford protein assay (Bio-Rad Laboratory, Hercules, CA, USA) (Bradford, 1976).

\section{Real-time reverse transcriptase polymerase chain reaction analysis}

Total RNA was isolated from cells using Trizol reagent according to the standard protocol. Approximately $2 \mu \mathrm{g}$ total RNA was used to generate first strand cDNA in each sample using SuperScript II RT with oligo(dT) 12-18 primers 
(Invitrogen, Carlsbad, CA, USA). Samples of total cDNA were amplified in each PCR reaction mixture of selected genes (Table 1). PCR amplification and analysis were achieved using a Smart Cycler thermal cycler (Cepheid, Sunnyvale, CA, USA) instrument. Thermocycling was done in a final volume of $25 \mu \mathrm{l}$ containing $0.5 \mu \mathrm{l}$ cDNA sample or calibrator; $0.3 \mu \mathrm{M}$ of each primer; $12.5 \mu 12 \times \mathrm{iO}^{\mathrm{TM}}$ SYBR Green Supermix (Bio-Rad Laboratory). After denaturing of cDNA at $95^{\circ} \mathrm{C}$ for $3 \mathrm{~min}$, the cycling conditions were as follows: forty cycles consisting of denaturation at $95^{\circ} \mathrm{C}$ for $12 \mathrm{~s}$, annealing at $56^{\circ} \mathrm{C}$ (for $\mathrm{ALP}$ ), $58^{\circ} \mathrm{C}$ (for $\mathrm{OPG}$ ), $56^{\circ} \mathrm{C}$ (for RANKL) or $55^{\circ} \mathrm{C}$ (for glyceraldehyde-3-phosphate dehydrogenase; GAPDH) for $12 \mathrm{~s}$, and extension at $72^{\circ} \mathrm{C}$ for $18 \mathrm{~s}$. A melting curve analysis was performed after the completion of Smart Cycler analysis and the PCR products were subjected to electrophoresis on a $1 \%$ agarose gel, visualised, and photographed under UV illumination. Expected band lengths were $597 \mathrm{bp}$ for ALP, $441 \mathrm{bp}$ for OPG, 396bp for RANKL and $452 \mathrm{bp}$ for GAPDH. GAPDH was chosen as the reference gene for RTPCR analysis. For quantification of RT-PCR product, standard curves of the threshold cycle against the amount of input cDNA for both target and reference gene were generated by dilution of cDNA extracted from an untreated control sample (a calibrator). The relative abundance of RT-PCR products in each unknown sample was then derived from these standard curves based on the measured threshold cycle levels for both target and reference genes, and was expressed as the target:reference ratio.

\section{Immunoblotting}

Conditioned media from cultured cells were collected and concentrated with Microcon-10 (Millipore Corp., Bedford, MA, USA). Equal amounts of concentrated proteins $(20 \mu \mathrm{g})$ were separated by SDS-PAGE on $10 \%$ reducing gels and transblotted to polyvinyldiene fluoride membranes (Immobilin-P; Millipore Corp.). Immunoblotting was performed after blocking non-specific binding on the membrane with $5 \%$ non-fat milk. The blots were probed firstly with polyclonal rabbit antihuman OPG (1:1000; Peprotech EC Ltd, London, UK) as the primary antibody, followed by incubation with the goat anti-rabbit antibody conjugated with horseradish peroxidase (1:2000; Santa Cruz Biotechnology, Inc., Santa Cruz, CA, USA) for $1 \mathrm{~h}$. Finally, the antigen-antibody complexes were detected using an enhanced chemiluminescence reagent and visualised by the Lumi-Imager with the software Lumi
Analyst version 3.10 (Roche, Mannheim, Germany). Transferred membrane was also stained with Coomassie brilliant blue after immunodetection. The intensities of the protein bands for different lanes were compared to ensure that samples under different treatment were equally loaded.

\section{Statistical analysis}

Data are reported as mean values with their standard errors. The non-paired Student's $t$ test was used to calculate statistical significance between the control group and each treatment group. Statistical analysis of dose responses was performed by one-way ANOVA. $P<0.05$ was considered statistically significant.

\section{Results}

Effects of genistein and parathyroid hormone on cell proliferation

The effects of genistein, $\mathrm{E}_{2}$ or PTH on cell proliferation were determined using the MTT assay. Treatment of human osteoblastic SaOS-2 cells with vehicle, genistein $\left(10^{-8}\right.$ to $\left.10^{-6} \mathrm{M}\right)$, $\mathrm{E}_{2}\left(10^{-8} \mathrm{M}\right)$ or PTH $\left(10^{-8} \mathrm{M}\right)$, for $48 \mathrm{~h}$ did not alter the cell proliferation rate (Fig. 1 (a); $P>0.05$ ). These results are in agreement with those reported previously, i.e. that $\mathrm{E}_{2}$ has no effect on the proliferation of SaOS-2 cells (Slootweg et al. 1992; Rao et al. 1994; Nasu et al. 2000). Similarly, the cell proliferation rate was not altered in SaOS-2 cells that were co-treated with PTH and $10^{-8} \mathrm{M}-\mathrm{E}_{2}$ or varying concentrations of genistein (Fig. 1 (b); $P>0.05$ ).

\section{Regulation of alkaline phosphatase activity and mRNA expression by genistein}

SaOS-2 cells predominantly express the ER $\beta$ isoform and produce ALP in culture. ALP activity can be considered as an osteoblastic phenotype marker and thus an osteoblastic differentiation index in SaOS-2 cells (Murray et al. 1987). Preliminary experiments indicated that ALP activities increased in a timedependent manner (24-72 h), and could be detected optimally at $72 \mathrm{~h}$ (data not shown). As shown in Fig. 2 (a), $\mathrm{E}_{2}\left(10^{-8} \mathrm{M}\right)$ had no effect on the ALP activity of SaOS-2 cells $(P>0.05)$, while genistein $\left(10^{-8}\right.$ to $\left.10^{-6} \mathrm{M}\right)$ increased the ALP activity in a dose-dependent manner $(P<0 \cdot 05)$. Co-treatment of SaOS-2 cells with oestrogen antagonist ICI $182780\left(10^{-6} \mathrm{M}\right)$ completely inhibited the increase of ALP activity induced by genistein

Table 1. Primers used for reverse transcriptase polymerase chain reactions and real-time reverse transcriptase polymerase chain reactions

\begin{tabular}{|c|c|c|c|c|}
\hline Primer & Sequence & Orientation & Product size (bp) & Temperature $\left({ }^{\circ} \mathrm{C}\right)$ \\
\hline Alkaline phosphatase & $\begin{array}{l}\text { GTGGACTATGCTCACAACAA } \\
\text { GGAGAAATACGTTCGCTAGA }\end{array}$ & $\begin{array}{l}\text { Sense } \\
\text { Antisense }\end{array}$ & 597 & 56 \\
\hline Osteoprotegrin & $\begin{array}{l}\text { GAACCCCAGAGCGAAATACA } \\
\text { CGCTGTTTTCACAGAGGTCA }\end{array}$ & $\begin{array}{l}\text { Sense } \\
\text { Antisense }\end{array}$ & 441 & 58 \\
\hline RANKL & $\begin{array}{l}\text { ATGGTGTACGTCACTAAAAC } \\
\text { GTGTTCTCTACAAGGTCAAG }\end{array}$ & $\begin{array}{l}\text { Sense } \\
\text { Antisense }\end{array}$ & 396 & 56 \\
\hline GAPDH & $\begin{array}{l}\text { ACCACAGTCCATGCCTACAC } \\
\text { TTCACCACCCTGTTGCTGTA }\end{array}$ & $\begin{array}{l}\text { Sense } \\
\text { Antisense }\end{array}$ & 452 & 55 \\
\hline
\end{tabular}

RANKL, receptor activator of NF-kB ligand; GAPDH; glyceraldehyde-3-phosphate dehydrogenase. 


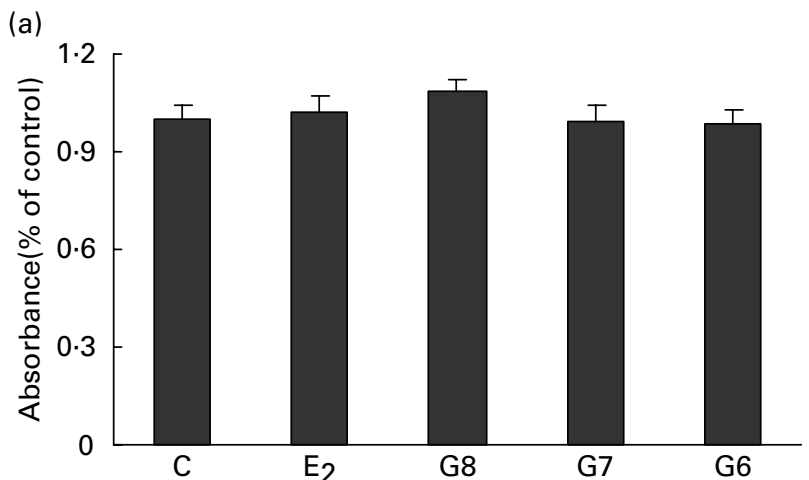

(b)

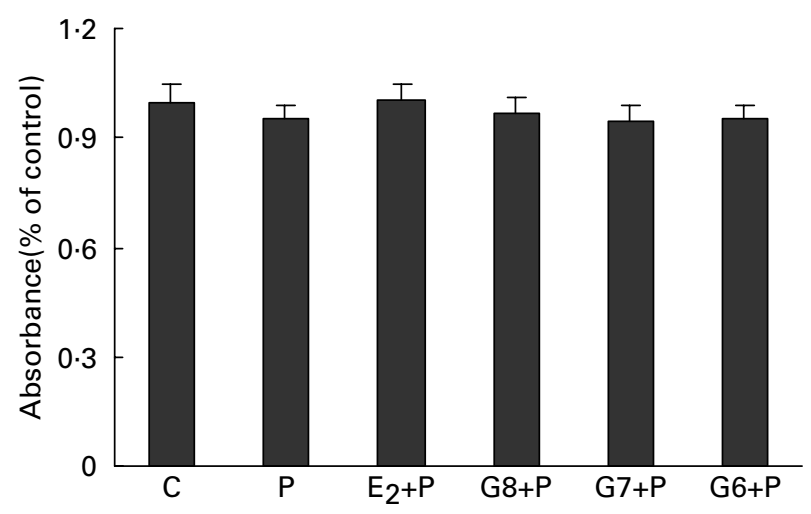

Fig. 1. Effects of $17 \beta$-oestradiol $\left(E_{2}\right)$, genistein and parathyroid hormone (PTH) on cell proliferation in human SaOS-2 cells. (a) SaOS-2 cells were treated variously with vehicle (control; C), $10^{-8}(\mathrm{G} 8), 10^{-7}(\mathrm{G} 7)$ or $10^{-6}$ (G6) $\mathrm{M}$-genistein or $10^{-8} \mathrm{M}-\mathrm{E}_{2}$ for $48 \mathrm{~h}$. Cell proliferation rate was determined by 3-[4,5-dimethylthiazol 2-yl]-2,5-diphenyltetrazolium bromide assay. This result is representative of three independent experiments. Values are means, with their standard errors represented by vertical bars. No significant change was found in the cell proliferation rate of SaOS-2 cells in response to treatment with genistein or $\mathrm{E}_{2}$. (b) SaOS-2 cells were treated with vehicle (control; C), $10^{-8} \mathrm{M}-\mathrm{E}_{2}$ or $10^{-8}$ (G8), $10^{-7}$ (G7) or $10^{-6}$ (G6) M-genistein for $24 \mathrm{~h}$, followed by treatment with PTH (P) for another $24 \mathrm{~h}$. This result is representative of three independent experiments. Values are means, with their standard errors represented by vertical bars. No significant change was found in the cell proliferation rate of SaOS-2 cells in response to the combined treatment.

(Fig. 2 (b); $P<0 \cdot 05$ ). The results indicated that genistein could stimulate SaOS-2 cell differentiation at dietary-achievable concentrations and these effects were ER-dependent. To determine whether $E_{2}$ or genistein could regulate ALP expression transcriptionally, SaOS-2 cells were treated either with vehicle, $\mathrm{E}_{2}\left(10^{-8} \mathrm{M}\right)$, or genistein $\left(10^{-8}\right.$ to $\left.10^{-6} \mathrm{M}\right)$ for $48 \mathrm{~h}$. The results shown in Fig. 3 indicate that the mRNA expression of ALP did not change in response to treatment with either $\mathrm{E}_{2}$ or genistein $(P>0.05)$. Thus, it appears that genistein regulated ALP activity post-transcriptionally.

\section{Modulating action of genistein on parathyroid hormone- induced alkaline phosphatase activity}

To determine if genistein and $\mathrm{E}_{2}$ modulated the effects of PTH on osteoblastic differentiation, their combined effects on ALP activities were determined in SaOS-2 cells. ALP activities were assayed upon pre-treatment of SaOS-2 cells with either genistein, $\mathrm{E}_{2}$, or its vehicle for $24 \mathrm{~h}$, followed by co-incubation with PTH for another $48 \mathrm{~h}$ so that the activities could be detected in SaOS-2 cells at the optimal duration of exposure $(72 \mathrm{~h})$. As shown in Fig. 4, PTH $\left(10^{-8} \mathrm{M}\right)$ alone significantly increased ALP activity $(P<0 \cdot 05)$. The increase in ALP activity by PTH was augmented by pre-treatment of SaOS-2 cells with genistein in a dose-dependent manner $(P<0.05)$. PTH-induced ALP activity was maximally augmented by 2.7 times following pre-treatment with $10^{-7} \mathrm{M}$-genistein. Pretreatment with $E_{2}\left(10^{-8} \mathrm{M}\right)$ also has positive effects on the PTH-induced ALP activity (Fig. 4; $P<0 \cdot 05$ ). The observed positive effect of $E_{2}$ and PTH is consistent with the results reported in a previous study (Rao et al. 1994). The combined effect of genistein and PTH on ALP gene expression was also determined. ALP gene expression was not modulated by PTH in the presence or absence of $E_{2}$ or genistein pre-treatment (data not shown).
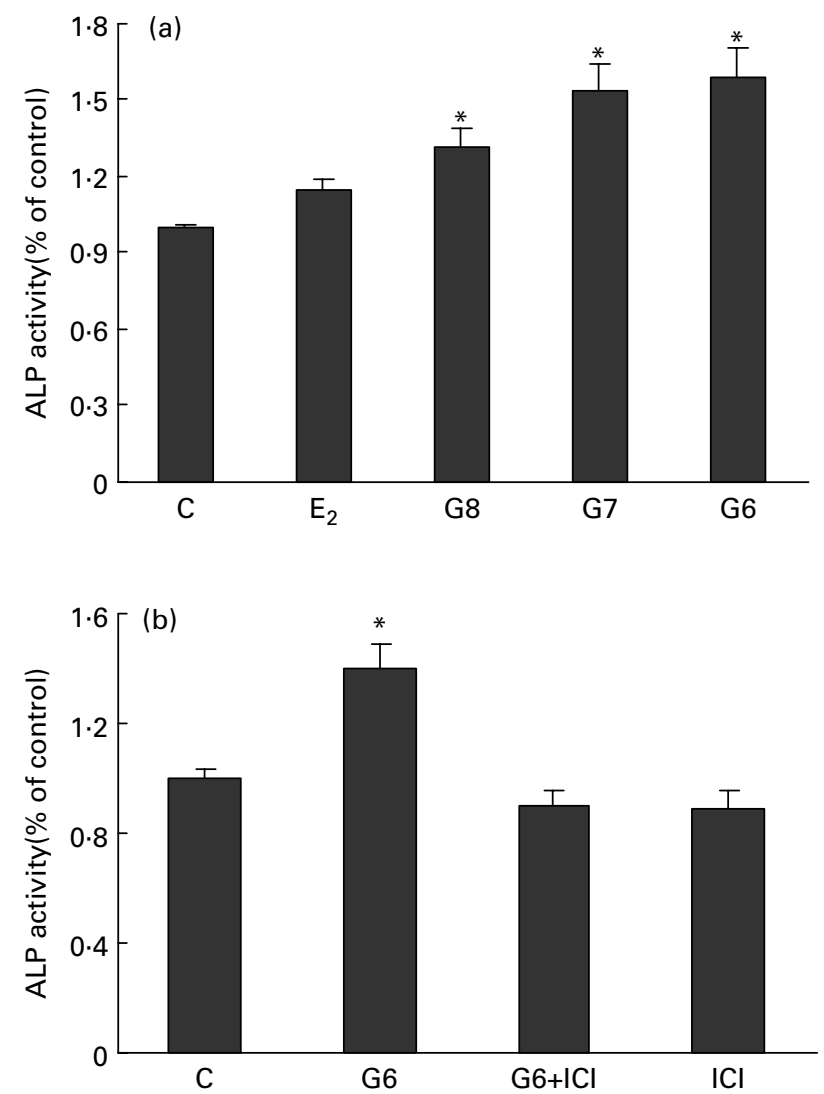

Fig. 2. Effects of $17 \beta$-oestradiol $\left(E_{2}\right)$ and genistein on alkaline phosphatase (ALP) activity in human SaOS-2 cells. (a) SaOS-2 cells were cultured and treated variously with vehicle (control; C), $10^{-8}$ (G8), $10^{-7}$ (G7) or $10^{-6}$ (G6) M-genistein or $10^{-8} \mathrm{M}-\mathrm{E}_{2}$ for $72 \mathrm{~h}$. (b) SaOS-2 cells were cultured and treated with vehicle (control; C) or $10^{-6}$ (G6) M-genistein in the presence of $10^{-6} \mathrm{M}-\mathrm{ICl} 182780$ (7 $\alpha$-[9-[(4,4,5,5,5-pentafluoropentyl)sulfonyl]nonyl]-estra-1,3,5(10)-triene-3,17 $\beta$-diol). Then the cell lysates were used for ALP activity detection. Results were obtained from four independent experiments. Values are means, with their standard errors represented by vertical bars. Genistein, but not $E_{2}$, increased ALP activity in a dosedependent manner. ICI 182780 completely abolished the induction of ALP activity by genistein. * Mean value was significantly different from that for the control $(P<0.05)$. 


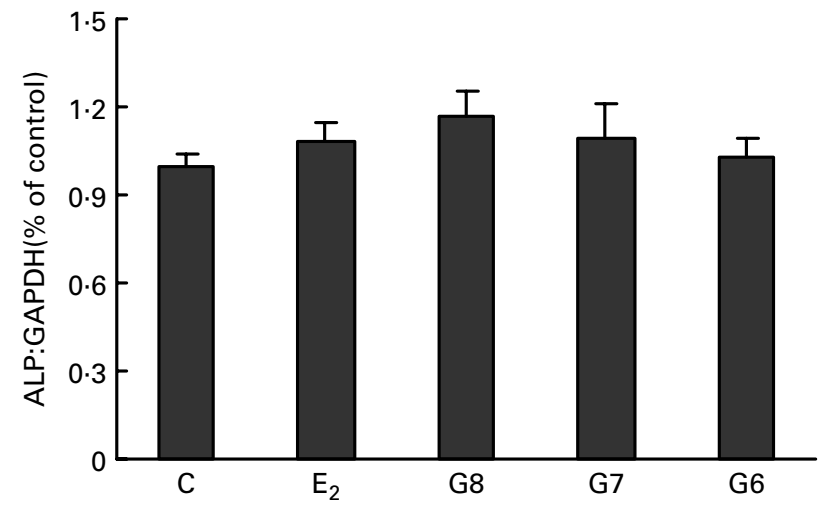

Fig. 3. Effects of $17 \beta$-oestradiol $\left(E_{2}\right)$ and genistein on alkaline phosphatase (ALP) mRNA expression in human SaOS-2 cells. SaOS-2 cells were cultured and treated variously with vehicle(control; C), $10^{-8}$ (G8), $10^{-7}$ (G7) or $10^{-6}$ (G6) $M$-genistein or $10^{-8} M-E_{2}$. Total RNA were isolated and subjected to real-time RT-PCR analysis for detection of ALP, and the control glyceraldehyde-3-phosphate dehydrogenase (GAPDH) transcript. The mRNA expression level of ALP is shown as a ratio to the expression of GAPDH. Results were obtained from three independent experiments. Values are means, with their standard errors represented by vertical bars. ALP mRNA expression level was not altered in SaOS-2 cells in response to treatment with $\mathrm{E}_{2}$ or genistein.

\section{Effects of genistein on osteoprotegrin protein expression}

OPG is a secretary protein produced by osteoblastic cells. The effect of genistein on its expression in SaOS-2 cells was therefore determined by measuring the amount of OPG secreted in the culture medium. The effects of genistein on OPG protein expression in SaOS-2 cells are shown in Fig. 5. $\mathrm{E}_{2}$ (at $10 \mathrm{~nm}$ ) failed to alter the OPG protein expression in SaOS-2 cells, while genistein stimulated OPG protein secretion in a dose-dependent manner (Fig. 5 (a); $P<0 \cdot 05$ ). The stimulation of OPG protein secretion by $10^{-7} \mathrm{M}$ - and $10^{-6} \mathrm{M}$-genistein was 1.8- and 1.6-fold, respectively. The up regulation of OPG protein expression was completely blocked by oestrogen antagonist ICI 182780 (Fig. 5 (b); $P<0 \cdot 05$ ), suggesting that the effects of genistein on OPG protein expression were ERdependent. The immunoblots were stained with Coomassie brilliant blue to ensure that samples were equally loaded, and the differences observed between the samples were due to different treatment (data not shown).

\section{Effects of genistein on osteoprotegrin and receptor activator of nuclear factor- $\kappa B$ ligand mRNA expression}

OPG and RANKL are both expressed by osteoblastic cells and are involved in modulating osteoclastic cell activities. The secretion of OPG by osteoblastic cells could decrease the interactions of RANKL with RANK located on the osteoclastic cell surface, thereby preventing the induction of osteoclastic activities. Thus, the RANKL:OPG mRNA expression ratio could be used as an indirect index to evaluate the potential effects of different treatments on bone remodelling. An increase in the RANKL:OPG ratio suggests an increase in ability of the osteoblastic cells to recruit osteoclasts, whereas a decrease in the ratio suggests the reduction of osteoclastic cell recruitment. To determine if genistein could modulate osteoclastic cell activities, the effects of different concentrations of genistein

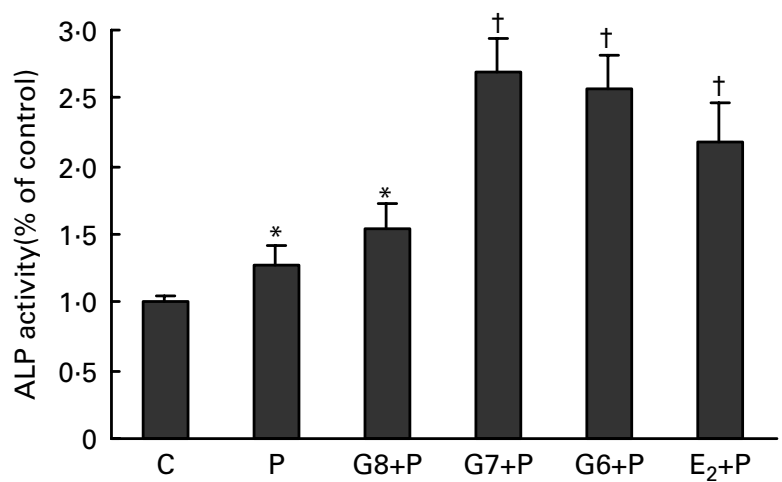

Fig. 4. Modulating action of genistein or $17 \beta$-oestradiol $\left(E_{2}\right)$ on parathyroid hormone (PTH)-induced alkaline phosphatase (ALP) activity. SaOS-2 cells were cultured and treated variously with vehicle (control; C), $10^{-8}(\mathrm{G} 8), 10^{-7}$ (G7) or $10^{-6}(\mathrm{G} 6) \mathrm{M}$-genistein or $10^{-8} \mathrm{M}-\mathrm{E}_{2}$ for $24 \mathrm{~h}$, followed by treatment with $10^{-8} \mathrm{M}-\mathrm{PTH}(\mathrm{P})$ for another $48 \mathrm{~h}$. Cell lysates were then used for ALP activity detection. Results were obtained from three independent experiments. Values are means, with their standard errors represented by vertical bars. PTH treatment increased ALP activity. Pre-treatment with genistein augmented PTH-induced ALP activity in a dose-dependent manner. * Mean value was significantly different from that for the control $(P<0.05)$. † Mean values were significantly different from the group of $C, P$ and $G 8+P$ $(P<0.05)$.

on OPG and RANKL mRNA expression in SaOS-2 cells were determined. The expression of OPG and RANKL mRNA were analysed by quantitative real-time RT-PCR. As shown in Fig. 6 (a), treatment of SaOS-2 cells with $E_{2}$ significantly increased OPG mRNA expression $(P<0.05)$ but did not significantly alter the level of RANKL mRNA expression (Fig. 6 (b); $P>0.05)$. The differential effects of $\mathrm{E}_{2}$ on RANKL and OPG mRNA expression in SaOS-2 cells resulted in a significant decrease in the RANKL:OPG ratio (Fig. 6 (c); $P<0.05$ ), suggesting that $\mathrm{E}_{2}$ exerts inhibitory effects on the recruitment of osteoclastic cells. The effect of genistein on OPG mRNA expression was similar to $\mathrm{E}_{2}$, in which treatment of SaOS-2 cells with $10^{-6} \mathrm{M}$-genistein resulted in a 1.4 -fold increase in OPG mRNA expression $(P<0 \cdot 05)$. However, $10^{-6}$ M-genistein also increased RANKL mRNA expression by more than 1.3fold (Fig. $6(\mathrm{~b}) ; P<0.05$ ). As a result, at $10^{-6} \mathrm{M}$, the effect of genistein on induction of OPG mRNA expression in SaOS-2 cells was counteracted by its inductive effects on RANKL mRNA expression. Thus, genistein $\left(10^{-8}\right.$ to $\left.10^{-6} \mathrm{M}\right)$ did not alter the RANKL:OPG ratio in SaOS-2 cells (Fig. 6 (c); $P<0 \cdot 05)$.

Modulating action of genistein on parathyroid hormoneinduced osteoprotegrin and receptor activator of nuclear factor- $\kappa B$ ligand $m R N A$ expressions

To determine if genistein could modulate the effects of PTH on osteoclastogenesis, the expressions of OPG and RANKL mRNA in SaOS-2 cells co-treated with PTH and genistein were determined. The present results indicate that genistein can alter OPG and RANKL expressions only at higher concentration $\left(10^{-7}\right.$ and $\left.10^{-6} \mathrm{M}\right)$. Thus, SaOS-2 cells were pre-treated with either genistein at higher concentrations, $\mathrm{E}_{2}\left(10^{-8} \mathrm{M}\right)$ or its vehicle for $24 \mathrm{~h}$, followed by co-treatment with $10^{-8} \mathrm{M}$ PTH for another $24 \mathrm{~h}$. Fig. 7 (a) and Fig. 7 (b) show that treatment of SaOS-2 cells with PTH alone resulted in a significant 
(a) C

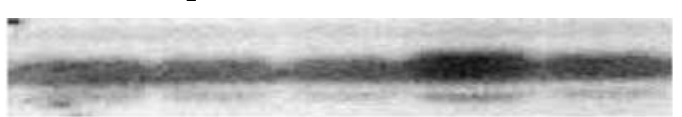

(b)

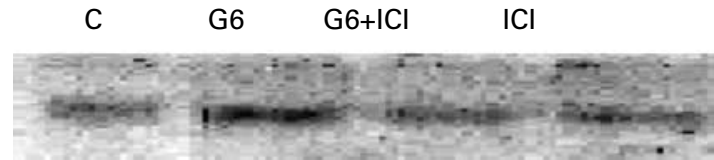

$\overline{0}$
0
0
0
0
4
0
0
$\frac{1}{0}$
$\frac{0}{0}$
0
0
$\frac{0}{x}$
0
$\frac{1}{0}$
0
0
$\frac{0}{0}$
0
0
0

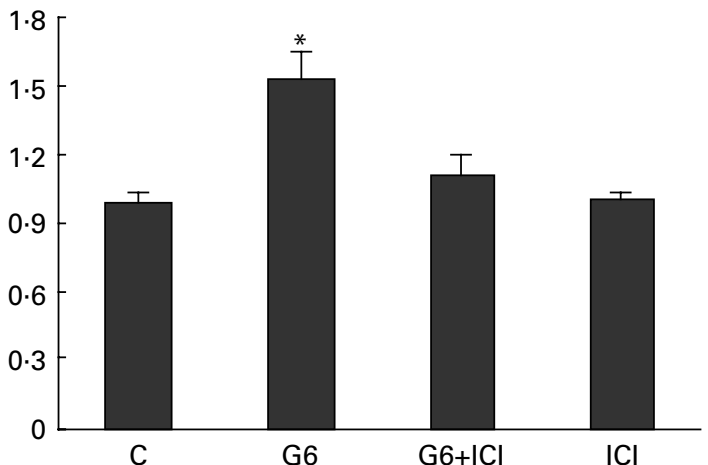

Fig. 5. Effects of $17 \beta$-oestradiol $\left(E_{2}\right)$ and genistein on osteoprotegrin (OPG) protein expression in human SaOS-2 cells. Proteins were isolated from the conditioned media and fractionated using 10\% SDS-PAGE and immunoblotted with antibody against OPG. (a) SaOS-2 cells were cultured and treated variously with vehicle (control; C), $10^{-8}$ (G8), $10^{-7}$ (G7) or $10^{-6}$ (G6) $\mathrm{M}$-genistein or $10^{-8} \mathrm{M}-\mathrm{E}_{2}$. (b) SaOS-2 cells were cultured and treated with vehicle (control; C) or $10^{-6}$ (G6) $\mathrm{M}$-genistein in the presence of $10^{-6} \mathrm{M}-\mathrm{ICl}$ 182780 (7 $\alpha$-[9-[(4,4,5,5,5-pentafluoropentyl)sulfonyl]nonyl]-estra-1,3,5(10)-triene-3,17 3 -diol). The results shown are representative of three independent experiments. Values are means, with their standard errors represented by vertical bars. Genistein stimulated OPG protein secretion in a dose-dependent manner. $E_{2}$ failed to alter the OPG protein expression. ICI $182780 \mathrm{com}-$ pletely abolished the induction of OPG protein expression by genistein. ${ }^{*}$ Mean value was significantly different from that for the control $(P<0.05)$.

decrease in the expression of OPG mRNA as well as a significant increase in the expression of RANKL mRNA $(P<0 \cdot 05)$. The resulting RANKL:OPG ratio was significantly increased upon treatment with PTH in SaOS-2 cells (Fig. 7 (c); $P<0 \cdot 05$ ), confirming the action of PTH in modulating osteoclastic activities. Pre-treatment of SaOS-2 cells with genistein or $\mathrm{E}_{2}$ could reverse the inhibitory effect of PTH on OPG gene expression (Fig. 7 (a)). In contrast, pre-treatment of SaOS-2 cells with $\mathrm{E}_{2}$, but not genistein, completely attenuated the induction of RANKL mRNA expression by PTH
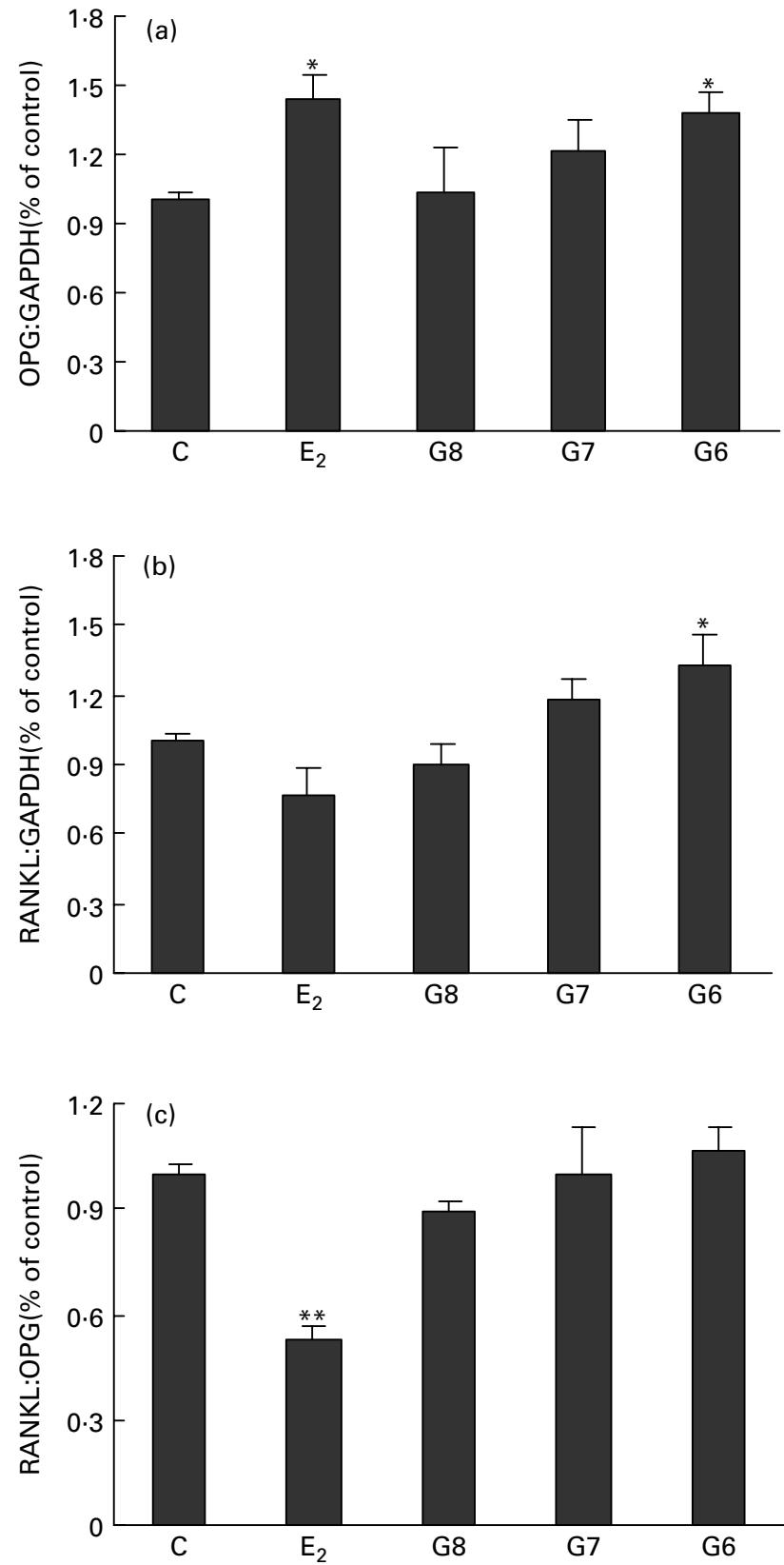

Fig. 6. Effects of $17 \beta$-oestradiol $\left(E_{2}\right)$ and genistein on osteoprotegrin (OPG) and receptor activator of nuclear factor- $\mathrm{kB}$ ligand (RANKL) mRNA expressions in human SaOS-2 cells. SaOS-2 cells were cultured and treated variously with vehicle (control; C), $10^{-8} \mathrm{M}-\mathrm{E}_{2}$, or $10^{-8}(\mathrm{G} 8), 10^{-7}$ (G7) or $10^{-6}$ (G6) M-genistein. Total RNA were isolated and subjected to real-time RT-PCR analysis for detection of OPG (a), RANKL (b) and the control glyceraldehyde3-phosphate dehydrogenase (GAPDH) transcript. The mRNA expression level of OPG and RANKL are shown as a ratio to the expression of GAPDH. The graphical results shown are representative of three independent experiments. Values are means, with their standard errors represented by vertical bars. (c) The graphical representation of the RANKL:OPG ratio. Genistein increased the mRNA expression of OPG and RANKL in a dose-dependent manner. $E_{2}$ significantly increased OPG mRNA expression. Mean value was significantly different from that for the control: ${ }^{*} P<0.05$, ${ }^{* *} P<0.01$.

(Fig. 7 (b)). Taken together, it appears that genistein and $E_{2}$ can prevent the up regulation of the RANKL:OPG ratio by PTH in osteoblastic cells (Fig. 7 (c); $P<0.05$ ). These results suggest that the beneficial effect of genistein and $E_{2}$ on 

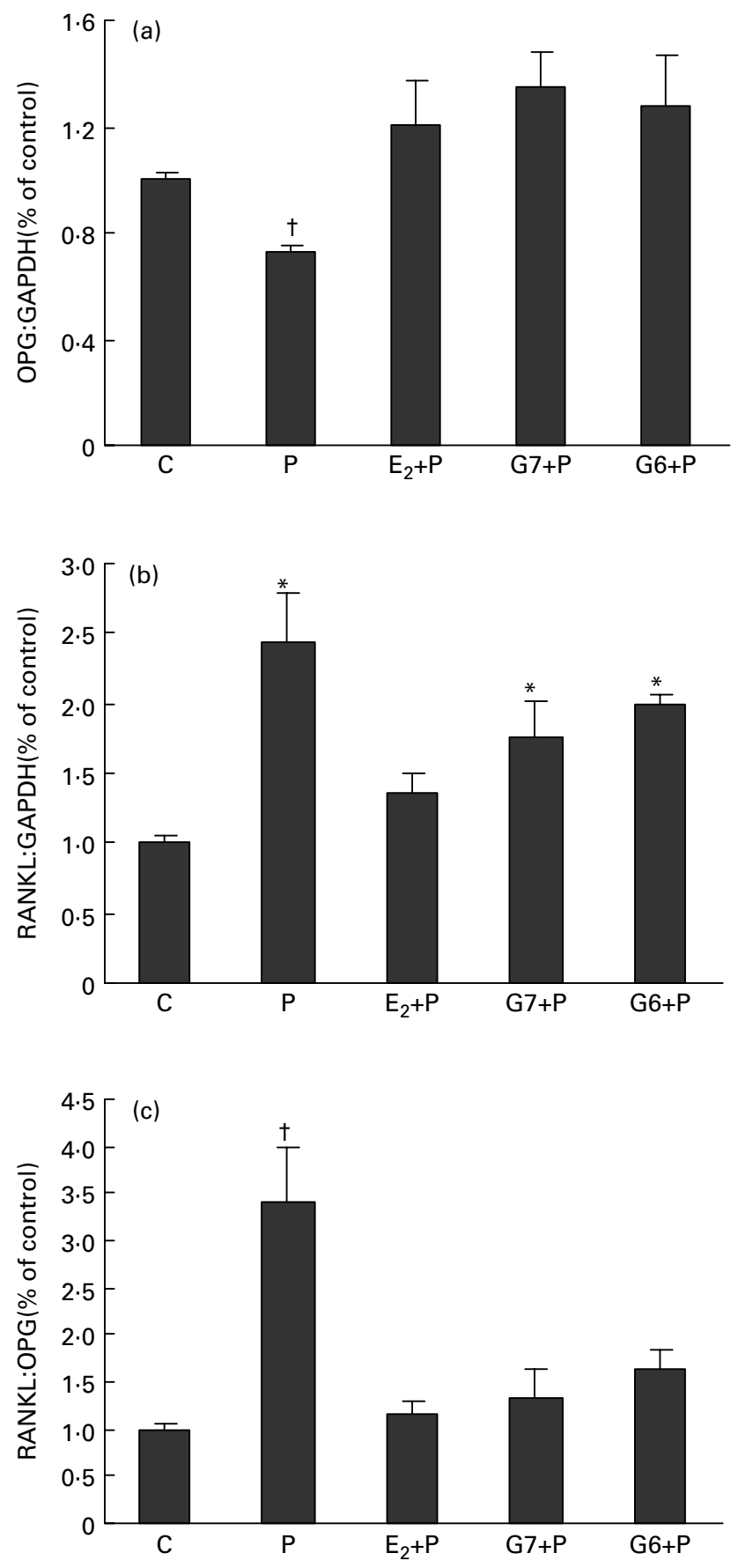

Fig. 7. Modulating action of $17 \beta$-oestradiol $\left(E_{2}\right)$ or genistein on osteoprotegrin (OPG) and receptor activator of nuclear factor-кB ligand (RANKL) mRNA expressions regulated by parathyroid hormone (PTH) in human SaOS-2 cells. SaOS-2 cells were cultured and treated variously with vehicle (control; $\mathrm{C}$ ), $10^{-8}$ $M-E_{2}$, or $10^{-7}(G 7)$ or $10^{-6}(G 6) \mathrm{M}$-genistein for $24 \mathrm{~h}$, followed by treatment with $10^{-8} \mathrm{M}$-PTH $(\mathrm{P})$ for another $24 \mathrm{~h}$. Total RNA were isolated and subjected to real-time RT-PCR analysis for detection of the OPG (a), RANKL (b) and the control glyceraldehyde-3-phosphate dehydrogenase (GAPDH) transcript. The mRNA expression levels of OPG and RANKL are shown as ratios to the expression of GAPDH. The graphical results shown are representative of three independent experiments. Values are means, with their standard errors represented by vertical bars. (c) The graphical representation of the RANKL:OPG ratio. Pre-treatment with genistien or $E_{2}$ could completely reverse the PTHinduced increase in the RANKL:OPG ratio. * Mean value was significantly different from that for the control $(P<0.05)$. $†$ Mean value was significantly different from that for the control and the other treated groups $(P<0.05)$. bone health is partially mediated by modulating the effects of PTH on OPG and RANKL expression in osteoblastic cells.

\section{Discussion}

Several phenotypic markers of osteoblastic cells, including cell proliferation (MTT) and ALP, were used in the present study to determine the effects of genistein and PTH on human osteoblastic SaOS-2 cells. The results indicate that genistein, but not $E_{2}$, significantly increased ALP activity in a dose-dependent manner, supporting its role in modulating osteoblastic cell differentiation. It appears that the stimulatory effect of genistein on ALP activity is ER-dependent and that cell proliferation as determined by the MTT assay is not affected by genistein or $\mathrm{E}_{2}$ treatment. The present results are consistent with those reported by others (Rao et al. 1994; Nasu et al. 2000), that $\mathrm{E}_{2}$ has no significant effect on ALP activity or cell proliferation and that neither $E_{2}$ nor genistein modulate ALP gene expression in SaOS- 2 cells. These results indicate that cell proliferation and ALP gene expression might not be involved in the anabolic effects of $E_{2}$ and genistein in this bone cell model system.

Previous studies showed that serum genistein and isoflavone levels increased in a dose-dependent manner in response to in vivo administration of genistein in animals (Santell et al. 2000) as well as soya food consumption in human subjects (King \& Bursill, 1998). However, the plasma level of genistein was seldom over $1 \mu \mathrm{mol} / \mathrm{l}$ even in a population with high traditional soya food intake. Thus, in the present study, the dietary achievable concentrations of genistein ranging from $10^{-8}$ to $10^{-6} \mathrm{M}$ were chosen in order to mimic these in vivo conditions.

The equilibrium of RANKL and OPG expression plays an important role in controlling bone remodelling. To our knowledge, only three studies have looked at the effect of genistein on RANKL gene expression in osteoblastic cell lines (Chen \& Anderson, 2002; Viereck et al. 2002; Chen et al. 2003) However, mRNA signals of RANKL were not detectable in these cell model systems. The present study is the first to report that RANKL gene expression is detectable in SaOS-2 cells and could be regulated by genistein. Genistein (at $1 \mu \mathrm{M}$ ) produced a 1.3-fold increase in RANKL gene expression. However, the stimulatory effect on RANKL gene expression did not occur in SaOS-2 cells in response to treatment with $10^{-8}$ and $10^{-7} \mathrm{M}$-genistein, indicating that the effect of genistein on RANKL expression was dose-dependent.

Genistein was recently reported to have stimulatory effects on OPG mRNA levels and protein secretion in several different osteoblastic cells lines, including $\mathrm{OB}, \mathrm{hFOB}$ and MC3T3 cells (Chen \& Anderson, 2002; Viereck et al. 2002; Chen et al. 2003). In the present study, the effects of genistein on the steady-state level of OPG mRNA and protein production in human SaOS-2 cells were assessed. Genistein significantly increased OPG protein and mRNA expression in a dose-dependent manner. The increase in OPG protein secretion induced by genistein appears to be ER-dependent, as co-treatment of SaOS-2 cells with ICI 182780 completely abolished the induction of OPG protein secretion by genistein.

PTH was shown to act bi-directionally on osteoblastic SaOS-2 cells in the present study. PTH $\left(10^{-8} \mathrm{M}\right)$ treatment 
significantly increased ALP activity, suggesting that PTH could modulate osteoblastic cell differentiation and has an anabolic effect on bone. On the other hand, PTH significantly decreased OPG mRNA expression and stimulated RANKL mRNA expression. The increase in the RANKL:OPG ratio in SaOS-2 cells by PTH as demonstrated in the present study is in agreement with the well-known role of PTH in inducing bone resorption. The results indicate that PTH could potentially increase osteoclastic cell recruitment by increasing the RANKL:OPG ratio in osteoblastic cells.

Increasing evidence suggests that oestrogen might modulate the action of PTH in bone (Masiukiewicz et al. 2000). An association between oestrogen deficiency and the rise in serum PTH was reported previously (Khosla et al. 1997). For women, receiving oestrogen therapy could prevent the increase in PTH levels associated with the menopause and reverse virtually all age-related increase in bone resorption induced by PTH (Khosla et al. 1997; Masiukiewicz et al. 2000). The present results are consistent with previous reports (Rao et al. 1994; Nasu et al. 2000), i.e. that the PTH-induced ALP activity was further increased in response to pre-treatment with $\mathrm{E}_{2}$. At the same time, $\mathrm{E}_{2}$ can exert its anabolic effect on bone through the up regulation of OPG gene expression and the down regulation of the RANKL:OPG ratio in this cell model system. Most importantly, $\mathrm{E}_{2}$ pre-treatment can completely reverse the induction of RANKL gene expression and the inhibition of OPG gene expression by PTH. These results indicate as a possible mechanism that $\mathrm{E}_{2}$ could modulate the effect of PTH by stimulating osteoblastic cell differentiation and inhibiting osteoclastogenesis, thereby promoting bone formation in osteoblastic cells.

The present results also demonstrate that genistein could modulate the action of PTH in osteoblastic cells. PTH-induced ALP activity was further increased in SaOS-2 cells in response to pre-treatment with genistein. Pre-treatment of SaOS-2 cells with $10^{-7}$ and $10^{-6}$ M-genistein modestly attenuated PTHinduced RANKL mRNA expression and significantly reversed the inhibition of OPG mRNA expression by PTH. Thus, genistein mimics the effect of $\mathrm{E}_{2}$ in modulating the stimulatory effects of PTH on ALP expression as well as reversing the inductive effects of PTH on osteoclastogenesis via its modulation of the RANKL:OPG ratio. The present findings suggest beneficial effects of genistein on bone health associated with an oestrogen-deficient state.

In conclusion, the present data demonstrate the anabolic effects of phyto-oestrogens in human SaOS-2 osteoblastic cells. PTH acted bi-directionally on osteoblastic SaOS-2 cells by stimulating ALP activity, inducing RANKL gene expression and inhibiting OPG gene expression. In addition, the present study demonstrates that the anabolic effect of oestrogen in osteoblastic SaOS-2 cells was at least partly mediated through the modulation of the RANKL-OPG system. Furthermore, both genistein and oestrogen can augment PTH-induced ALP activity and attenuate the induction of osteoclastogenesis by PTH in SaOS-2 cells. The results of the present study provide new insights for understanding the molecular actions of genistein in osteoblastic cells. Most importantly, as genistein is a major type of dietary phyto-oestrogens commonly found in soya products, the present study provides the mechanistic basis for supporting the observed bone-protective effects reported previously in both clinical and epidemiological studies. Thus, a diet high in phyto-oestrogen content might be helpful for postmenopausal women with high circulating PTH levels to protect against bone loss and prevent the development of osteoporosis.

\section{Acknowledgements}

The authors would like to thank the State Key Laboratory of Chinese Medicine and Molecular Pharmacology for providing support in carrying out the present study. The study was supported by the Areas of Excellence Scheme Established under the University Grants Committee of the Hong Kong Special Administrative Region, China (AOE/P-10/01), the Area of Strategic Development Grant of the Hong Kong Polytechnic University (A014) and the Central Allocation Grant from the Research Committee of the Hong Kong Polytechnic University (APC-80, G-W105, G-YC81).

\section{References}

Alekel DL, Germain AS, Peterson CT, Hanson KB, Stewart JW \& Toda T (2000) Isoflavone-rich soy protein isolate attenuates bone loss in the lumbar spine of perimenopausal women. Am J Clin Nutr 72, 844-852.

Anderson JB, Chen XW \& Garner SC (2000) Effects of genistein on MT3T3-E1, and osteoclast-like cell in relation to expression of estrogen receptors and during cell differentiation. J Nutr 130, $660 \mathrm{~S}-667 \mathrm{~S}$.

Anderson JJ, Ambrose WW \& Garner SC (1998) Biphasic effects of genistein on bone tissue in the ovariectomized, lactating rat model. Proc Soc Exp Biol Med 217, 345-350.

Anonymous (1994) Assessment of fracture risk and its application to screening for postmenopausal osteoporosis. Report of a WHO Study Group. World Health Organ Tech Rep Ser 843, 11-23.

Bradford MM (1976) A rapid and sensitive method for the quantitation of microgram quantities of protein utilizing the principle of protein-dye binding. Anal Biochem 72, 248-254.

Bucay N, Sarosi I, Dunstan CR, et al. (1998) Osteoprotegerindeficient mice develop early onset osteoporosis and arterial calcification. Genes Dev 12, 1260-1268.

Chen X \& Anderson JJB (2002) Effects of isoflavones on osteoblast proliferation and differentiation. J Nutr 132, 616S Abstr.

Chen X, Garner SC, Quarles LD \& Anderson JJ (2003) Effects of genistein on expression of bone markers during MC3T3-E1 osteoblastic cell differentiation. J Nutr Biochem 14, 342-349.

Cusack S, Jewell C \& Cashman KD (2001) The effect of estrogen and selected phytoestrogens on cell viability and molecular markers of SaOS-2 osteoblast-like activity. Ann Nutr Metab 45, 228 Abstr.

Deady J (2004) Clinical monograph: hormone replacement therapy. J Manag Care Pharm 10, 33-47.

Dempster DW, Cosman F, Parisien M, Shen V \& Lindsay R (1993) Anabolic actions of parathyroid hormone on bone. Endocr Rev 14, 690-709.

Denizot F \& Lang R (1986) Rapid colorimetric assay for cell growth and survival. Modifications to the tetrazolium dye procedure giving improved sensitivity and reliability. J Immunol Methods 89, $271-277$.

Goldwyn S, Lazinsky A \& Wei H (2000) Promotion of health by soy isoflavones: efficacy, benefit and safety concerns. Drug Metabol Drug Interact 17, 261-289.

Greendale GA, FitzGerald G, Huang MH, Sternfeld B, Gold E, Seeman T, Sherman S \& Sowers M (2002) Dietary soy isoflavones and bone mineral density: results from the study of women's health across the nation. Am J Epidemiol 155, 746-754. 
Greenfield EM, Horowitz MC \& Lavish SA (1996) Stimulation by parathyroid hormone of interleukin-6 and leukemia inhibitory factor expression in osteoblasts in an immediate-early gene response induced by cAMP signal transduction. $J$ Biol Chem 271, 10984-10989.

Huang YF, Harrison JR, Lorenzo JA \& Kream BE (1998) Parathyroid hormone induces interleukin-6 heterogenous nuclear and messenger RNA expression in murine calvarial organ cultures. Bone 23, 327-332.

Khosla S, Atkinson EJ, Melton LJ III \& Riggs BL (1997) Effects of age and estrogen status on serum parathyroid hormone levels and biochemical markers of bone turnover in women: a populationbased study. J Clin Endocrinol Metab 82, 1522-1527.

King RA \& Bursill DB (1998) Plasma and urinary kinetics of the isoflavones daidzein and genistein after a single soy meal in humans. Am J Clin Nutr 67, 867-872.

Kong YY, Yoshida H, Sarosi I, et al. (1999) OPGL is a key regulator of osteoclastogenesis, lymphocyte development and lymph-node organogenesis. Nature 397, 315-323.

Lacey DL, Timms E, Tan HL, et al. (1998) Osteoprotegerin ligand is a cytokine that regulates osteoclast differentiation and activation. Cell 93, 165-176.

Lauderdale DS, Jacobsen SJ, Furner SE, Levy PS, Brody JA \& Goldberg J (1997) Hip fracture incidence among elderly AsianAmerican populations. Am J Epidemiol 146, 502-509.

Masiukiewicz US, Mitnick M, Grey AB \& Insogna KL (2000) Estrogen modulates parathyroid hormone-induced interleukin-6 production in vivo and in vitro. Endocrinology 141, 2526-2531.

Massion CG \& Frankenfeld JK (1972) Alkaline phosphatase: lability in fresh and frozen human serum and in lyophilized control material. Clin Chem 18, 366-373.

Mei J, Yeung SS \& Kung AW (2001) High dietary phytoestrogen intake is associated with higher bone mineral density in postmenopausal but not premenopausal women. J Clin Endocrinol Metab 86, $5217-5221$.

Morabito N, Crisafulli A, Vergara C, et al. (2002) Effects of genistein and hormone-replacement therapy on bone loss in early postmenopausal women: a randomized double-blind placebo-controlled study. J Bone Miner Res 17, 1904-1912.

Murray E, Provvedini D, Curran D, Catherwood B, Sussman H \& Manolagas S (1987) Characterization of a human osteoblastic osteosarcoma cell line (SAOS-2) with high bone alkaline phosphatase activity. J Bone Miner Res 2, 231-238.

Nasu M, Sugimoto T, Kaji H \& Chihara K (2000) Estrogen modulates osteoblast proliferation and function regulated by parathyroid hormone in osteoblastic SaOS-2 cells: role of insulin-like growth factor (IGF)-I and IGF-binding protein-5. $J$ Endocrinol 167, $305-313$.

Onyia JE, Libermann TA, Bidwell J, Arnold D, Tu Y, McClelland P \& Hock JM (1997) Parathyroid hormone (1-34)-mediated interleukin-6 induction. J Cell Biochem 67, 265-274.

Potter SM, Baum JA, Teng H, Stillman RJ, Shay NF \& Erdman JW Jr (1998) Soy protein and isoflavones: their effects on blood lipids and bone density in postmenopausal women. Am J Clin Nutr 68, Suppl. 6, 1375S-1379S.

Rao LG, Wylie JN, Sutherland MS \& Murray TM (1994) 17 Betaestradiol and parathyroid hormone potentiate each other's stimulatory effects on alkaline phosphatase activity in SaOS-2 cells in a differentiation-dependent manner. Endocrinology 134, 614-620.

Ross PD, Norimatsu H, Davis JW, Yano K, Wasnich RD, Fujiwara S, Hosoda Y \& Melton LJ III (1991) A comparison of hip fracture incidence among native Japanese. Japanese Americans, and American Caucasians. Am J Epidemiol 133, 801-809.

Santell RC, Kieu N \& Helferich WG (2000) Genistein inhibits growth of estrogen-independent human breast cancer cells in culture but not in athymic mice. J Nutr 130, 1665-1669.

Slootweg MC, Ederveen AG, Schot LP, Schoonen WG \& Kloosterboer HJ (1992) Oestrogen and progestogen synergistically stimulate human and rat osteoblast proliferation. J Endocrinol 133, R5-R8.

Valachovicova T, Slivova V \& Sliva D (2004) Cellular and physiological effects of soy flavonoids. Mini Rev Med Chem 4, 881-887.

Viereck V, Grundker C, Blaschke S, Siggelkow H, Emons G \& Hofbauer LC (2002) Phytoestrogen genistein stimulates the production of osteoprotegerin by human trabecular osteoblasts. $J$ Cell Biochem 84, 725-735.

Yamagishi T, Otsuka E \& Hagiwara H (2001) Reciprocal control of expression of mRNAs for osteoclast differentiation factor and OPG in osteogenic stromal cells by genistein: evidence for the involvement of topoisomerase II in osteoclastogenesis. Endocrinology 142, 3632-3637.

Yao GQ, Sun B, Hammond EE, Spencer EN, Horowitz MC, Insogna KL \& Weir EC (1998) The cell-surface form of colony-stimulating factor-1 is regulated by osteotropic agents and supports formation of multinucleated osteoclast-like cells. J Biol Chem 237, 4119-4129.

Yasuda H, Shima N, Nakagawa N, et al. (1998) Osteoclast differentiation factor is a ligand for osteoprotegerin/osteoclastogenesisinhibitory factor and is identical to TRANCE/RANKL. Proc Natl Acad Sci U S A 95, 3597-3602. 